\title{
Research on the Efficiency of Universities Technology Transfer in
}

\author{
Shaanxi \\ Duan Jie $^{1, a}$ Fu Xinwei ${ }^{1, a}$, Bai Hailin ${ }^{2, b}$ \\ 1,2 Northwestern Polytechnical University, Shaanxi xi 'an 710072 \\ The western industrial economy research institute of Northwestern Polytechnical University, \\ Shaanxi xi 'an 710072 \\ a fuxinwei@nwpu.edu.cn,duanjieyong@163.com, ㅎ18710707348@163.com
}

\begin{abstract}
Key word.Technology transfer;Efficiency;DEA
Abstract. Shaanxi province is a big province of education in China. It has rich science and technology resources.And its technology output level is very high. However, the efficiency of technology transfer is very low. This paper first studies the present situation of Shaanxi province university technology transfer, next take the 7 universities in Shaanxi province as samples, using DEA method to measure the efficiency of technology transfer.Through empirical Study result we obtained the conclusion that the technology transfer efficiency about Shaanxi universities is not high.
\end{abstract}

\section{Introduction}

Shaanxi is a major province of education in China,there are 81 ordinary colleges and universities of which there are 7 schools with 211 projects, and 3 schools of 985 . They have trained highly qualified personnel in all walks of life for the country. Although it is located in Northwest China, universities in Shaanxi have always paid more attention to the improvement of scientific research level.In 2015, the Shaanxi private science and Technology Service Center established in 1993 was officially renamed the Shaanxi technology transfer center,.It is an international demonstration center for technology transfer.These universities, on the one hand, make use of their own talents and resources to carry out technical cooperation with relevant enterprises.Enterprises providing funds, equipment, training venues, the school is responsible for the research achievements of science and technology and related personnel training. the other hand, they, through intermediaries for technology transfer.At the same time, the government also attaches great importance to the transfer of technology in universities.However, Shaanxi Province, like other provinces in China, the efficiency of technology transfer is not high.

\section{Index system and model design}

\section{Model selection}

As for the empirical analysis methods of technology transfer efficiency in universities, DEA and SFA are widely adopted in china.Compared with other methods, such as entropy weight grey relational analysis, SPA and AHP, the DEA method is not affected by subjective factors. It is very objective and simple to operate.DEA model is divided into C2R model and B2C model, the former to "scale pay the same" as the premise, but for technology transfer, it will certainly involve changes in technology, resulting in changes in the size of the remuneration.So this paper using the scale of 
compensation Change the B2C model.In this model, if the comprehensive efficiency value is equal to 1 , then DEA is valid, if the efficiency value is not equal to 1 , then DEA invalid.

\section{Index system}

The scholar circles on government funding and funding for science and technology differences, so we put these two items are included in the input index system .We used university science and technology expenditures to illustrate the amount of investment for science and technology. Because the staff and funds are matching so the $\mathrm{R} \& \mathrm{D}$ personnel into the target as an input.where $\mathrm{R} \& \mathrm{D}$ includes both full-time and including part-time researchers; As for output index, science and technology activity is mainly in order to obtain benefits, we set the following index system with the number of technology transfer contracts, the actual transfer of income and the number of papers published as the output indicators.Combined with the availability of real data and the index system selected by related scholars we establish the following index system:

Table 1 Index system

\begin{tabular}{ccc}
\hline First level index & Secondary index & Third index \\
\hline Input index & Personnel input & R\&D personnel input \\
& & Government funds input \\
& Funds input & Expenditure of science and \\
& & technology \\
Output index & Output & Actual transfer income \\
& & Number of papers published \\
\hline
\end{tabular}

\section{Empirical Study}

In order to make the results comparable, we selected 2015 of the data to calculate, the original data are as follows:

Table 2 original data

\begin{tabular}{ccccccc}
\hline & $\begin{array}{c}\text { Number } \\
\text { of } \\
\text { contracts } \\
\text { signed }\end{array}$ & $\begin{array}{c}\text { Actual } \\
\text { transfer } \\
\text { income }\end{array}$ & $\begin{array}{c}\text { Number } \\
\text { of papers } \\
\text { published }\end{array}$ & $\begin{array}{c}\text { R\&D } \\
\text { personnel } \\
\text { input }\end{array}$ & $\begin{array}{c}\text { Govern } \\
\text { ment funds } \\
\text { input }\end{array}$ & $\begin{array}{c}\text { Expendi } \\
\text { science } \\
\text { and } \\
\text { technology }\end{array}$ \\
\hline $\begin{array}{c}\text { Xi`an Jiaotong University } \\
\text { Northwestern Polytechnical }\end{array}$ & 82 & 35398 & 6295 & 2147 & 784066 & 693343 \\
$\quad \begin{array}{c}\text { University } \\
\text { Xidian University }\end{array}$ & 66 & 1910 & 4869 & 1441 & 756631 & 1023192 \\
$\begin{array}{c}\text { Chang'an University } \\
\text { North West Agriculture and Fore } \\
\text { stry University }\end{array}$ & 191 & 28610 & 773 & 402 & 235977 & 614829 \\
$\begin{array}{c}\text { Shaanxi Normal University } \\
\text { Northwest University }\end{array}$ & 5 & 490 & 3820 & 1445 & 567676 & 316489 \\
\hline
\end{tabular}

\section{Efficiency analysis}

According to the data in Table 3.3, using the DEAP software, we obtained the following results. 
Table 3 Results of DEA

\begin{tabular}{|c|c|c|c|c|}
\hline & $\begin{array}{l}\text { Comprehensive } \\
\text { efficiency }\end{array}$ & $\begin{array}{l}\text { Technical } \\
\text { efficiency }\end{array}$ & Scale efficiency & \\
\hline Xi`an Jiaotong University & 0.956 & 1 & 0.956 & drs \\
\hline $\begin{array}{l}\text { Northwestern Polytechnical } \\
\text { University }\end{array}$ & 0.743 & 1 & 0.743 & drs \\
\hline Xidian University & 0.621 & 0.941 & 0.683 & drs \\
\hline Chang'an University & 1 & 1 & 1 & - \\
\hline $\begin{array}{l}\text { North West Agriculture and For } \\
\text { estry University }\end{array}$ & 0.61 & 1 & 0.61 & drs \\
\hline Shaanxi Normal University & 1 & 1 & 1 & - \\
\hline Northwest University & 0.517 & 0.614 & 0.843 & drs \\
\hline
\end{tabular}

According to the above data, the average of the technical transfer value of the Seven colleges in Shaanxi Province is 0.781.which indicates that the technology transfer efficiency of colleges and universities in Shaanxi Province is still not high, and it has not yet reached DEA valid, and there is still a lot of room for improvement.Among these seven universities only Chang'an University and Shaanxi Normal University, have achieved a comprehensive efficiency DEA effective.While the remaining five universities have not reached DEA effective.This shows there is a lot of room for improvement in resource allocation, and execution in that the 5 universities.However, from the fact that DEA is not equal to 1 is definitely good.For example, the Shaanxi Normal University in the above table, although its DEA value is 1, but in fact the actual technology transfer income only 5110 thousand dollars.In the DEA as long as the input unit is low enough, even if the decision unit value is very low, it also can achieve DEA effective.Some universities, such as Xi'an Jiao Tong University and Northwestern Polytechnical University, although the efficiency of DEA did not reach DEA effective, but the actual transfer of income in Shaanxi ranking is relatively forward.The delay of technology transfer will also cause the efficiency of technology transfer to be inefficient to a certain extent.We know that sometimes the input and output of the elements are often not produced in the same year.And some technologies from capital investment to transformation may take several years, which to some extent makes the technology transfer efficiency is not high.

From the specific technical efficiency and scale efficiency: Technical efficiency is the maximum output that can be obtained by a decision unit under the given input portfolio.As can be seen from the above table, Xi'an Jiao Tong University, Northwestern Polytechnical University, Chang'an University, Northwest Agriculture and Forestry University, Shaanxi Normal University technical efficiency reached technical efficiency effective.Universities with inefficient technical efficiency should strengthen the management of personnel and funds to improve the output level, so as to improve the efficiency of transfer.Some universities are affected by their scale efficiency, although their technical efficiency is effective, the comprehensive efficiency is not DEA effective.Scale efficiency, also called scale profit, examines whether the provinces and autonomous regions carry out technology transfer activities at the most appropriate scale of investment under the conditions of a certain level of Technology.From this point of view, only two universities' scale efficiency reached DEA efficient.This shows that the two universities have reached the best point of scale income, so these schools should maintain their existing scale for technical transfer.The remaining few universities are in the scale of diminishing returns.According to the model results, we conclude that the input and output do not match, so these universities should reduce the existing 
scale or adjust the input and output on the basis of the existing scale to improve the efficiency of DEA.

\section{Projection analysis}

Table 4 Projection results

\begin{tabular}{|c|c|c|c|c|c|c|}
\hline & $\begin{array}{l}\text { Number } \\
\text { of } \\
\text { contracts } \\
\text { signed }\end{array}$ & $\begin{array}{l}\text { Actual } \\
\text { transfer } \\
\text { income }\end{array}$ & $\begin{array}{l}\text { Number } \\
\text { of papers } \\
\text { published }\end{array}$ & $\begin{array}{c}\text { R\&D } \\
\text { personnel } \\
\text { input }\end{array}$ & $\begin{array}{c}\text { Govern } \\
\text { ment funds } \\
\text { input }\end{array}$ & $\begin{array}{l}\text { Expendi } \\
\text { ture of } \\
\text { science } \\
\text { and } \\
\text { technology }\end{array}$ \\
\hline Xi`an Jiaotong University & 0 & 0 & 0 & 0 & 0 & 0 \\
\hline $\begin{array}{c}\text { Northwestern Polytechnical } \\
\text { University }\end{array}$ & 0 & 0 & 0 & 0 & 0 & 0 \\
\hline Xidian University & 29 & 16729 & 210 & -9 & 0 & -167930 \\
\hline Chang'an University & 0 & 0 & 0 & 0 & 0 & 0 \\
\hline $\begin{array}{l}\text { North West Agriculture and Fore } \\
\text { stry University }\end{array}$ & 0 & 0 & 0 & 0 & 0 & 0 \\
\hline Shaanxi Normal University & 0 & 0 & 0 & 0 & 0 & 0 \\
\hline Northwest University & 0 & 0 & 898 & 0 & -53854 & 0 \\
\hline
\end{tabular}

It can be seen from the above table, the Xidian University, research and development personnel expenditure appears relative redundancy in 2015.In theory the number of technology transfer contract, actual transfer income and papers published should be increased on the basis of the existing 29, 16729 and 210 units in order to achieve DEA efficiency.As for Northwestern University can be reduced by 53 million 854 thousand yuan of government capital investment or increase 898 papers to achieve effective DEA efficiency . Represented by these universities, it illustrates the low efficiency of technology transfer in Shaanxi Province because of $r$ input redundancy and the lack of output.

\section{Conclusions}

From the above empirical analysis, we know that the technology transfer efficiency of "211" universities in Shaanxi Province, which is rich in manpower and capital, is not particularly high.Judging from the results of DEA, Shaanxi University of technology transfer efficiency is not high, partly because in a given level of technology, the output could not reach the maximum, on the other hand is due to unsuitable for technology transfer in the existing scale.The transfer of technology in universities is a complex process.All parties need to work together to improve the efficiency of technology transfer.

\section{Acknowledgments}

This work was financially supported by Xi'an Science and Technology Program Soft Science Project (NO. 2017112SF/RK006(7), Soft science project of Shaanxi science and technology program(2018KRM106),Project supported by the basic scientific research of Central University(3102016RW001)and Young teachers training project of Humanities, economics and law, Northwestern Polytechnical University (RWZZ2014-01). 


\section{References}

1. Alene, Hassan.Food production efficiency under traditional and improved technology in a developing economy: the case of farmers within and outside the extension package program in Ethiopia. Journal of Developing Areas.

2. JQ Li, LJ Yang, T Zhu.The study on effects of concurrent business on cultivated land use efficiency - based on empirical analysis of Gansu and Qinghai Province. Sustainable Agriculture Research

3. BV Shelyuto.Productivity and energy efficiency of cultivating perennial fodders in a raw material conveyor system in the north-eastern region of Belarus. Kormoproizvodstvo. 